\title{
Bacterial Inhibition and Antioxidant Activity of Probiotic Yoghurt Developed Using Microbial Isolates from Soymilk
}

\author{
E. J. Nya and I. D. Ufia
}

\section{ABSTRACT}

The aim of this study was to investigate the bacterial inhibition and antioxidant activities of probiotic yoghurts developed using microbial isolates from Soymilk. Bacterial inhibitory activity of yoghurt was evaluated against Staphyloccocus aureus, Bacillus subtillis, Escherichia coli and Pseudomonas flourescens by using the disk diffusion method. The yoghurt showed some inhibitory activities against all the organisms tested. Antioxidant activity of yoghurt was measured using three different methods- Diphenyl-1-picryl hydroxyl (DPPH) radical scavenging activity, lipid peroxidase assay and hydroxyl radical scavenging activity against Butylated hydroxyanisole (BHA) as standard. The results showed that probiotic yoghurt exhibits relative high antioxidant activities as compare to BHA. However, by implications this study suggests that probiotic yoghurt has some inhibitory activities against all the bacteria tested, also can be consider among the most promising functional foods for their antioxidant activity and ability to prevent oxidative damage and attendant ageing.

Keywords: Antioxidant, bacterial inhibition, prebiotic yoghurt, probiotic yoghurt.

\section{INTRODUCTION}

Probiotics is one of the science driven products that is known to enhanced reductions in disease risks and is defined as live micro-organisms which, when administered in adequate amounts, confer health benefits on the host [1][2]. However, "probiotic" is a Greek word meaning "for life" and is the opposite of the name antibiotic [3]. Today, probiotics have received global attention from researchers, product manufacturers, and consumers. The community of bacteria living in the human guts (about $100 \mathrm{M}$ microbes), influences health and plays a role in the aging process and disease development, most especially as seen in the activity of proteolytic bacteria which produce toxic substances in the large bowel. Proteolytic bacteria such as clostridia are part of the normal commensal gut flora, but produces toxic substances including phenols, indols and ammonia from proteins hydrolysis and these compounds are known to be responsible for the physiological changes associated with old age [2].

However, inhibitions of the growth of proteolytic bacteria have been achieved by the use of milk fermenting lactic-acid bacteria through low $\mathrm{pH}$ produced by the fermentation of lactose. Therefore, by implications the consumption of fermented milk products would inoculate the intestine with non-virulence lactic-acid bacteria with reduced intestinal $\mathrm{pH}$ and thus colonized and suppress the growth of proteolytic bacteria. This process also could effectively inhibit the
Published Online: July 19, 2021

ISSN: 2684-5199

DOI: $10.24018 /$ ejbio.2021.2.4.174

\section{E. J. Nya*}

Dept. of Biotechnology, Akwa Ibom State University, Mkpat Enin, P.M.B 1167, Uyo, Nigeria.

(e-mail: nya.elijah@yahoo.com) I. D. Ufia

Dept. of Biotechnology, Akwa Ibom State University, Mkpat Enin, P.M.B 1167, Uyo, Nigeria.

(e-mail: ifiok.uffia@ ${ }^{@}$ ahoo.com)

*Corresponding Author proliferation of pathogenic microorganisms such as Staphylococcus aureus, Escherichia coli, Campylobacter jejuni, Vibrio cholerae and coliform bacteria [4]-[5]. Bifidobacteria were the first line of probiotic, non-virulence bacteria isolated from a breast-fed infant. They are known to be dominant in the gut flora of breast-fed babies and possesses observed clinical benefits for treating diarrhea in infants. Their acclaimed mode of action is the colonization, dislodgement or displacement of proteolytic bacteria which cause gastrointestinal related disease.

In the present study we evaluate the inhibitory and antioxidant activities of probiotic yoghurts with the antioxidant activity of butylated hydroxyanisole (BHA) as standard. BHA is one of the widely used antioxidant in cosmetic and food industries [6]. It is used in preserving fats in foods such as in butter, meats, cereals, baked foods, chewing gum, snack foods and dehydrated potatoes. BHA has undergone the US Food and Drug Administration (USFDA), food additive evaluations and certifications [7]. However, there is evidence that certain persons may show difficulties in metabolizing BHA thereby having health and behavioural alterations [8]. This is why there have been renewed efforts in clinical studies and search for natural antioxidants worldwide. Interest in probiotic yoghurts has been intensified in recent years due to its health benefits and environmental friendliness. Principally with the emergence of antibiotic resistant plasmid, it has become reasonable to explore new sources of natural bioactive compounds with 
antioxidant and antimicrobial activities that could be used to assuage stress, minimized oxidative damage and ageing.

\section{MATERIALS AND METHODS}

\section{A. Preparation of Bacterial Isolates}

The bacteria used in the evaluation of inhibitory activities of yoghurt, Staphyloccocus aureus, Bacillus subtillis, Escherichia coli and Pseudomonas flourescens were raised in nutrient broth and incubated at $35^{\circ} \mathrm{C}$ for $24 \mathrm{~h}$. Inoculating loop full of these bacteria were transferred from the nutrient broth to sterile water and emulsified to a turbidity of McFarland 0.5 density. The absorbance was taken at $625 \mathrm{~nm}$ as 0.08 to $0.10\left(1.5 \times 10^{8}\right.$ cells/ $\left.\mathrm{mL}^{-1}\right)$. A drop $(0.1 \mathrm{~mL})$ of the organism suspension was then plated out on solid agar surface using spread technique and use for the evaluation at 24, 48 and $72 \mathrm{~h}$ incubation period.

\section{B. Preparation of Probiotic Microorganisms and} Inoculation of Milk

The probiotic starter culture containing Lactobacillus rhamnosus was prepared following the method of [9]. Briefly, the starter culture containing probiotic microorganisms were isolated from soymilk and added to sterile deMan, Rogosa and Sharpe MRS broth and then anaerobically incubated using gas packs at $37{ }^{\circ} \mathrm{C}$ for 16 hours. Fluid milk was then inoculated with a $1 \%(\mathrm{w} / \mathrm{v})$ sample of the probiotic broth mixture. The inoculated milk was then incubated at $37{ }^{\circ} \mathrm{C}$ for 18 hours then stored at $4{ }^{\circ} \mathrm{C}$ in an airtight container prior to use.

\section{Manufacturing of Probiotic Yogurt}

Standardized milk with $3 \%$ fat was heated to $85^{\circ} \mathrm{C}$ for 30 minutes, cooled to $40{ }^{\circ} \mathrm{C}$. After which an $8 \%(\mathrm{w} / \mathrm{v})$ sample of the standard yogurt cultures Lactobacillus delbrueckii subsp. bulgaricus and Steptococcus thermophilus was used to inoculate the milk. Then $4 \%(\mathrm{w} / \mathrm{v})$ sample of the prepared probiotic strain- Lactobacillus rhamnosus GR-1 was added and the overall mixture incubated at $37^{\circ} \mathrm{C}$ for six hours.

\section{Determination of Physicochemical Property}

The $\mathrm{pH}$ potential and Titratable acidity of the samples were measured using a pH meter (MA235, Milan, Italy) and determined by AOAC method respectively [10]. The Viscosity was measured by using viscometer according to [11]. Syneresis (contraction of a gel from the fluid) was determined by centrifuging yogurt at $350 \mathrm{~g}$ for $30 \mathrm{~min}$ and it was expressed as volume of separated whey per $100 \mathrm{ml}$ of yogurt [12].

\section{E. Determination of Bacterial Inhibitory Activity}

The antimicrobial property of the probiotic yoghurt was evaluated using the disk diffusion method as described by the National Committee for Clinical Laboratory Standard [13]. Antibiotics, ampicillin and penicillin were used to compare bacterial inhibition activity of the probiotic yoghurt. Paper disk of these antibiotics $(5 \mathrm{~mm})$ were placed on top of agar surface previously inoculated and grown with probiotic yoghurt sample suspension.

These plates were incubated at $35^{\circ} \mathrm{C}$ for 24,48 and $72 \mathrm{~h}$. The inhibition zones were measures at the end of the incubation period. This experiment was performed in triplicates and mean values were used.

\section{F. Antioxidant Activity}

The antioxidant activity of the probiotic yoghurt was measured using three different methods. Diphenyl-1-picryl hydroxyl (DPPH) radical scavenging activity, lipid peroxidase assay and hydroxyl radical scavenging activity against Butylated hydroxyanisole (BHA) as standard. The antioxidant activity was tested at the end of 24, 48 and $72 \mathrm{~h}$ incubation and compared with BHA as standard. The experiment was performed in triplicates and the mean values were used for statistical analysis.

\section{G. DPPH Radical Scavenging Activity}

This was evaluated following the method of [6]. Briefly, $0.004 \%(\mathrm{w} / \mathrm{v})$ of DPPH in $95 \%$ ethanol was prepared. $3.0 \mathrm{ml}$ of DPPH radical methanolic solution was mixed with $0.1 \mathrm{ml}$ of probiotic yoghurt sample; this was well vortexed and incubated for $30 \mathrm{~min}$ at $30^{\circ} \mathrm{C} /$ room temperature in the dark room. $95 \%$ ethanol was used as blank. Absorbance of both sample and the blank was measured. The antioxidant activity (AA) was taken as the percentage of DPPH scavenging activity given as:

$$
A A=\left(\frac{\text { Blank Absorbance }- \text { Sample Absorbance }}{\text { Blank Absorbance }}\right) \times 100 \text { (1) }
$$

\section{H. Lipid Peroxidase Assay}

Lipid peroxidase assay was estimated according to the method of [6], with minor modifications. The $0.1 \mathrm{~mL}$ of probiotic yoghurt sample and $0.4 \mathrm{~mL}$ of distilled water was mixed with $0.5 \mathrm{~mL}$ of $10 \%(\mathrm{v} / \mathrm{v})$ egg yolk solution. This mixture was well vortexed with $0.07 \mathrm{~mL}$ of $10 \mathrm{mM} \mathrm{FeSO}_{4}$ and incubated for $30 \mathrm{~min}$ at room temperature. Shortly, $1.5 \mathrm{~mL}$ of thiobarbituric acid solution, taken from $0.8 \%$ $(\mathrm{w} / \mathrm{v})$ thiobarbituric acid in $1.1 \%$ sodium dodecyl sulphate sample mixed well and heated for $60 \mathrm{~min}$ at $95{ }^{\circ} \mathrm{C}$ was added. After the sample was cooled, $5 \mathrm{~mL}$ of buta-1-ol was added. The mixture was centrifuged for $10 \mathrm{~min}$ at $3000 \mathrm{rpm}$. Supernatant was decanted and used. Absorbance was measured at $532 \mathrm{~nm}$. and $95 \%$ ethanol was used as control. The antioxidant activity was given as an inhibition percentage (IP) and calculated as:

$$
I P=\left(\frac{\text { Control Absorbance }- \text { Sample Absorbance }}{\text { Control Absorbance }}\right) \times 100
$$

\section{The Hydroxyl Radical Scavenging Activity}

The hydroxyl radical scavenging activity of the sample was measured following the method of [6], with modification. Briefly, $0.075 \mathrm{~mL}$ of sample was mixed with $0.45 \mathrm{~mL}$ of $0.2 \mathrm{M}$ sodium phosphate buffer, $\mathrm{pH} 7 ; 0.15 \mathrm{~mL}$ of $10 \mathrm{mM}$ of 2-deoxyribose; $0.15 \mathrm{~mL}$ of $10 \mathrm{mM}$ EDTA; $0.15 \mathrm{~mL}$ of $10 \mathrm{mM} \mathrm{FeSO}$; $0.15 \mathrm{~mL}$ of $10 \mathrm{mM}$ hydrogen peroxide and $0.525 \mathrm{~mL}$ distilled water. The sample was then incubated at $37{ }^{\circ} \mathrm{C}$ for $4 \mathrm{~h}$. After the incubation period, $0.75 \mathrm{~mL}$ of $2.8 \%(\mathrm{v} / \mathrm{v})$ trichloroacetic acid and $0.1 \%(\mathrm{v} / \mathrm{v})$ thiobarbituric acid was added. Then the sample was placed in boiling water for $10 \mathrm{~min}$. After which the absorbance of 
the sample was measured at $520 \mathrm{~nm}$ and ethanol was used as control. The antioxidant activity was given as an inhibition percentage and calculated as (2).

\section{RESULTS}

\section{A. Physicochemical Analysis}

The values of physicochemical parameters of the probiotic yogurt samples are shown in Table I. The kind of probiotic culture and incubation temperature significantly $(p<0.05)$ affected the physicochemical characteristics of these samples. Fermentation was stopped at $\mathrm{pH}$ 4.5-4.7 in all the samples. However, the samples reached the mentioned $\mathrm{pH}(4.5-4.7)$ at different periods. The sample- probiotic yoghurt Strain A - made using the mixture of Lactobacillus delbrueckii subsp. bulgaricus and Steptococcus thermophilus and incubated at $40{ }^{\circ} \mathrm{C}$ reached $\mathrm{pH}$ 4.5-4.7 in the shortest fermentation time (360 $\mathrm{min})$, while the sample strain- B of the prepared probiotic yoghurt containing Lactobacillus rhamnosus GR-1 incubated at $37{ }^{\circ} \mathrm{C}$ had the longest fermentation period (510 $\mathrm{min})$.

\section{B. Bacterial Inhibitory Activity}

The result showed $E$. coli among the tested microbes to be the most sensitive microorganism. Also, bacterial inhibitory effect of probiotic yoghurt was notice against B. subtilis with small diameter clearing zones (about $10 \mathrm{~mm}$ ) within 24 h incubation period. Bacterial inhibitory activity against $S$. aureus was observed only for the $48 \mathrm{~h}$ incubation period with small diameter zone, there was no effect against $P$. flourescens as can be seen in Fig. 1.

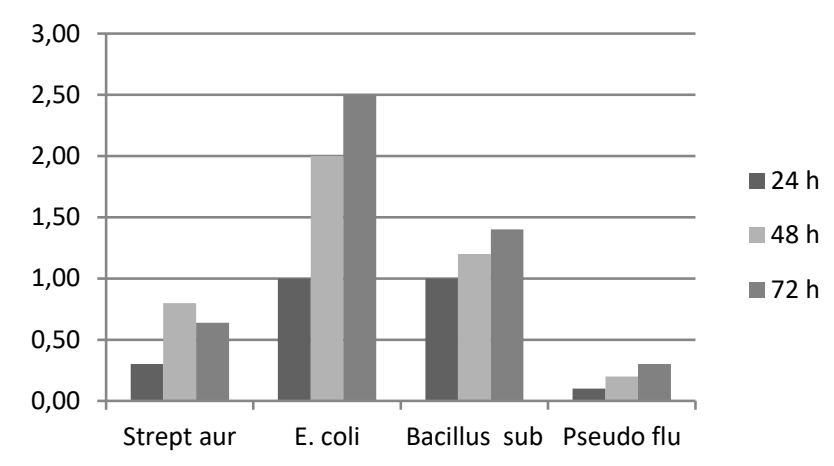

Fig. 1. Inhibition zones of bacterial inhibition activity *diameter in $\mathrm{mm}$ ) at 24,48 and $72 \mathrm{~h}$ of incubations.

\section{Antioxidant Activity}

DPPH radical scavenging showed the result of antioxidant activity of probiotic yoghurt for 24 and $48 \mathrm{~h}$ as increasing with the increasing concentration of sample inhibition, the percentage also increased. There were no significant differences of antioxidant activities during the incubation period of 24,48 and $72 \mathrm{~h}$ as compared with the standard (BHA concentration of 100 and $200 \mathrm{mg} / \mathrm{mL}$ ). However, $48 \mathrm{~h}$ incubation showed the lowest antioxidant activity as shown in Fig. 2.

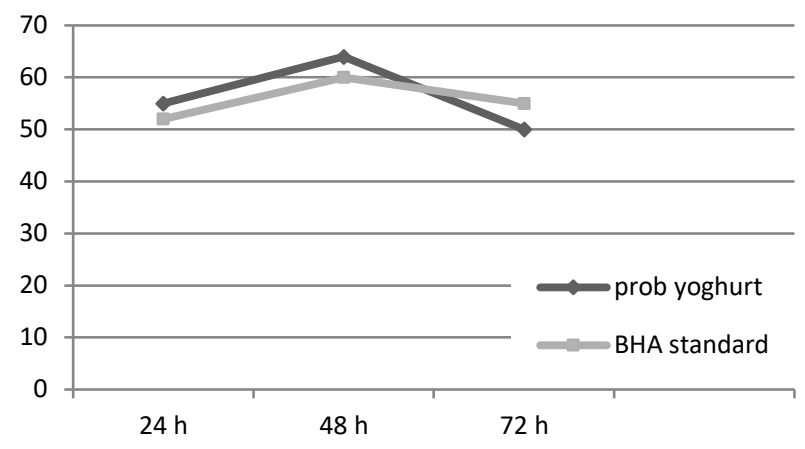

Fig. 2. Antioxidant activity (in \%) of probiotic yoghurt at 24, 48 and $72 \mathrm{~h}$ incubation period using DPPH method

\section{Hydroxyl Radical Scavenging Activity}

The antioxidant activity of probiotic yoghurt was higher than the antioxidant activity of standard BHA although there was significant difference. At the incubation period of 24 and $48 \mathrm{~h}$, there was increase antioxidant activity. (see Fig. 3)

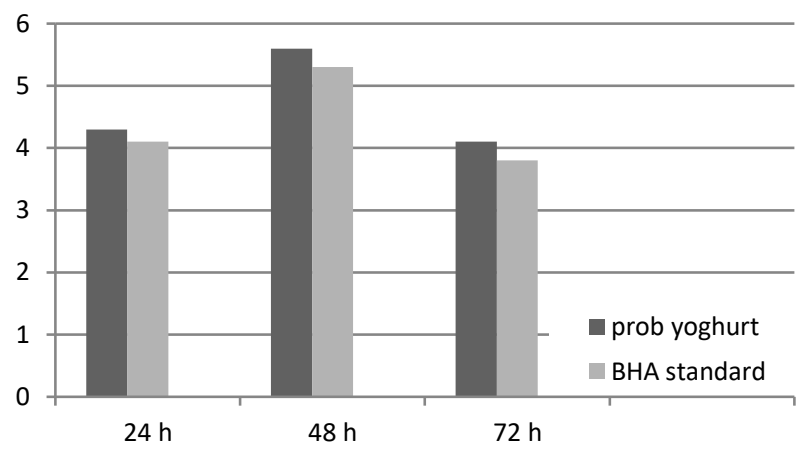

Fig. 3. Antioxidant activity (in \%) of probiotic yoghurt at 24,48 and $72 \mathrm{~h}$ incubation period using hydroxyl radical scavenging assay.

TABLE I: Physicochemical PROPERTIES OF PRobiotic Yogurt SAMPLES (VALUES ARE MEANS \pm SD)

\begin{tabular}{|c|c|c|c|c|c|c|}
\hline Treatment & Temperature $\left({ }^{\circ} \mathrm{C}\right)$ & $\begin{array}{l}\text { Fermentation time } \\
(\mathrm{min})\end{array}$ & $\mathrm{pH}(\min )$ & $\begin{array}{l}\text { Acidity increase rate } \\
\left({ }^{\circ} \mathrm{D} / \mathrm{min}\right)\end{array}$ & $\begin{array}{l}\text { Total Lactic acid } \\
(\mathrm{mg} / 100 \mathrm{mg})\end{array}$ & Viscosity $(\mathrm{CP})\left({ }^{\circ} \mathrm{D}\right)$ \\
\hline \multicolumn{7}{|l|}{$\begin{array}{l}\text { Probiotic } \\
\text { Yoghurt: }\end{array}$} \\
\hline \multirow{2}{*}{ Strain A } & $37^{\circ} \mathrm{C}$ & 360 & $4.5-4.7$ & 0.9 & 0.86 & 54.00 \\
\hline & $40^{\circ} \mathrm{C}$ & 420 & $4.5-4.7$ & 0.7 & 0.89 & 58.00 \\
\hline \multirow{2}{*}{ Strain B } & $37^{\circ} \mathrm{C}$ & 510 & $4.5-4.7$ & 0.8 & 0.70 & 53.00 \\
\hline & $40^{\circ} \mathrm{C}$ & 450 & $4.5-4.7$ & 0.7 & 0.75 & 67.00 \\
\hline
\end{tabular}

\section{DISCUSSION}

From the physiochemical property of the probiotic yogurt samples. It was shown that incubation at higher temperature $\left(37^{\circ} \mathrm{C}\right)$ for the mixture of Lactobacillus delbrueckii subsp. bulgaricus and Steptococcus thermophilus leads to decrease in fermentation time (360 $\mathrm{min})$, while the samples of the prepared probiotic strain- Lactobacillus rhamnosus GR-1 incubated at lowest temperature of $35{ }^{\circ} \mathrm{C}$ had the longest fermentation period (510 $\mathrm{min})$. This is probably due to the inadequate production of proteolytic activity by probiotic bacteria strain - Lactobacillus rhamnosus so it cannot breakdown protein and form free amino acids and small 
peptides within shortest possible time [14].

Fermentation resulted in decreased in the $\mathrm{pH}$ value, and thus increasing the acidity of the samples [5]. It has been shown earlier that lower $\mathrm{pH}$ which came as result of enhanced fermentation of the milk product may be responsible for inhibitory action against the proliferation of pathogenic microorganisms in foods [4]. The high acidity value observed in the samples may be due to this fermentation process. The acid production in yogurt depends on the growth of microorganisms. In line with this, [15] had reported that lactic acid bacteria grow well in soymilk but produce fewer organic acids. This acidity of yoghurt sample is also attributable to their ability to ferment the carbohydrates in soymilk. Reference [16] numerated prominent carbohydrates present in soymilk to include sucrose, raffinose and stachyose, whereas in milk it is lactose.

However, in this study, it was observed that probiotic yoghurt showed low viscosity. This is in agreement with the claim of commercial yoghurt manufacturers asserting that starter culture strains do not have any effect on texture and consequently can be used with little limitation in any product, in view of the fact that probiotic bacteria strain will prevail over such products during incubation. Furthermore, the addition of probiotic strains especially bifidobacteria, to the product (yoghurt) serves a basic role in increasing the texture and taste of the product [17].

The tested microorganisms used in evaluation of inhibitory activities of the probiotic yoghurt, (Staphyloccocus aureus, Bacillus subtillis, Escherichia coli and Pseudomonas flourescens) are known for their pathogenic activities ranging from gastrointestinal diseases such as diarrhea to problems of food contaminations in developing countries. Furthermore, they constitute major issues of public importance in public health despite advances in medical sciences [18]. Our findings showed that probiotic yoghurt contained some inhibitory compounds which prove to inhibit the growth of these microbes. The study suggests the present of bactriocins, hydrogen peroxide or lactic acids which might be responsible for this inhibitory activity. On the other hand, [2] had shown that probiotic bacteria are known to checkmate the growth of gut micro flora through exclusive colonization and enhanced competitive adhesion. The colonization of the gastrointestinal guts and epithelium surface is their frontline mode of actions. This is in line with this study; the data from this study showed that probiotic yoghurt exhibits enhanced bacterial inhibitory activity against tested pathogenic organisms. Thus, it can be used as an effective and safe prophylactic agent for controlling wide range of bacterial infections.

The effect of probiotic yogurt on the scavenging activity of DPPH radical showed significant activity as compared to the standard. This demonstrates that the antioxidant property of probiotic strains was in synergy with that of soymilk in their actions. In line with this, [19] had reported an enhanced scavenging activity of fermented milk which may be related to milk protein and soybean derived milk. In addition, the data in this study suggested that the increasing antioxidant activity observed with the probiotic yoghurt may be due to the ability of probiotic bacterial strains to synthesized bioactive compounds. This is in agreement with the report of [20]. These bioactive compounds are metabolites or phenolic compounds with antioxidant properties. The antioxidant activity of probiotic yoghurt is here demonstrated to be comparable to that generated by the synthetic antioxidants BHA used as standard. Butylated hydroxyanisole BHA is a well-known synthetic antioxidant used by many researchers as standard [21]. This implies that due to their tested and effective scavenging ability on free radicals, probiotic yoghurts could be said to possessed adequate antioxidant properties and is a potential candidate for use in functional foods as antioxidant dietary supplement for humans.

\section{REFERENCES}

[1] R. Fuller, "Probiotics in man and animals," The Journal of Applied Bacteriology" vol. 66, no. 5, pp. 365-78, May 1989.

[2] E.J. Nya, "Development of Probiotics as Biotechnology - Driven Product for Reducing the Incidence of Gastrointestinal Related Disease," International Journal of Science and Research (IJSR), vol. 4, issue 9, 2015.

[3] S.M. Sharifuzzaman, "Studies on Probiotics for the control of Vibriosis in rainbow trout (Oncorhynchus mykiss, Walbaum)" Ph.D. Thesis 2010. School of life sciences, Heriot Watt University, Edinburgh, UK., 2010.

[4] C. Duggan, J. Gannon and W. A Walker, "Protective nutrients and functional foods for the gastrointestinal tract," American Journal of Clinical Nutrition, vol. 75, No. 5, 2002, pp. 789-808, May 2002.

[5] S. Hekmat and L. Koba, "Fermented dairy products: Knowledge and consumption," Canadian Journal of Dietetic Practice and Research, vol. 67, No. 4, pp. 199-201, Feb. 2006.

[6] S. Deeseenthum and P. Jeleena, "Bacterial inhibition and antioxidant activity of kefir produced from thai jasmine rice milk," Biotechnology, vol 9, no 3, pp. 332-337, 2010.

[7] J R. Lupton, "Scientific substantiation of claims in the USA: focus on functional foods," European Journal of Nutrition, vol. 48, pp. 27-31, Dec. 2009

[8] S. Lyck, L. M Nilsson and A. Y Tamime, "Miscellaneous fermented milk products in fermented milk," Tamime, A. Y. (Ed). Blackwell Publishing, Oxford, UK. 2006.

[9] S. Hekmat and G. Reid, "Survival of Lactobacillus Reuteri RC-14 and Lactobacillus Rhamnosus GR-1 in milk," International Journal of Food Science \& Technology, vol. 42, No. 5, pp. 615-619, March 2007.

[10] AOAC. 'Official Methods of Analysis of the AOAC', 15th Edn. (ed. S. Williams). Association of Official Analytical Chemists, Arlington, 2002.

[11] I. Sodini, J. Montella, P.Tong, "Journal of the Science of Food and Agriculture", 2005, vol. 85, pp. 853-859, 2005.

[12] C. Gonzalez-Martinez, M. Becerra, M. Chafer, A. Albors, J. M Carot, A. Chiralt, "Trends food," Science and Technology, 2002, 13, pp. 334-340, 2002.

[13] NCCLS 'Performance standards for antimicrobial disk susceptibility tests' 7th Ed., NCCLS, Wayne, PA, 2000.

[14] I. Garcia-Cano, D. Rocha-Mendoza, J. Ortega-Anaya, "Lactic acid bacteria isolated from dairy products as potential producers of lipolytic, proteolytic and antibacterial proteins," Applied Microbial Biotechnology, vol. 103, pp. 5243-5257, April 2019.

[15] K. Liu, "Soybean: Chemistry, technology and utilization," Chapman and Hall, NewYork, 1997.

[16] R. Pinthong, R. Macraw and J. Disk, "Carbohydrates present in soymilk," Journal of Food Technology, vol. 15, pp. 661-667,1980.

[17] P. Rezvan, G. Atefeh, F. Masoud and M. A. Mahnaz, "Production of probiotic soy yogurt", Annals of Biological Research, vol. 3, no 6, pp. 2750-2754, 2012.

[18] U. Fagundes-Neto and I. C Scaletsky, "The gut at war. The consequences of enteropathogenic E. coli infection as a factor of diarrhea and malnutrition", Sao Paulo Medical Journal, vol.118: pp. 21- 29, January 2000.

[19] J. Chen, H. Lindmark-Mansson, L. Gorton and B. Akesson, "Antioxidant capacity of bovine milk as assayed by spectrophotometric and amperometric methods," International Dairy Journal, vol. 13, pp. 927-935, June 2003. 
European Journal of Biology and Biotechnology www.ejbio.org

[20] I. Y. Sandy and E J. Nya, "Development of probiotic yoghurt using microbial isolates from soymilk," Journal of Biopesticides and Agriculture, vol. 1, pp. 78 -89, 2015.

[21] D. L. Madhavi, R. S, Singhal, and Kulkami, "Technological aspect of food antioxidants", In: Food antioxidants: Technological, toxicological and health perspective' Madhavi, Deshpande and Salunkhe (Eds). Marcel Dekker, New York, pp. 159-265, 1996.

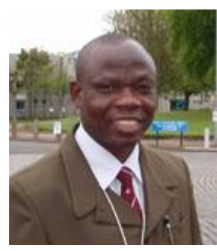

E. J. Nya hailed from Ini LGA of Akwa Ibom State, Nigeria. He has his first degree B. Agric. with specialty in Agronomy, from the University of Uyo, Nigeria in 2000. Had his M. Sc. in 2004 from Michael Okpara University of Agriculture, Umudike, Nigeria in plant genetics from where he went to Heriot Watt University, Edinburgh, Scotland for his $\mathrm{PhD}$ and graduated in 2009. He has amassed more than ten years of unbroken research experience in the field of agricultural biotechnology. He is currently heading the department of biotechnology in his affiliated university. His research interest span from development of plant based dietary supplement for mitigation of disease to development of immunostimulant, prophylaxis, probiotics for enhanced disease resistance and to genetic studies for improvement in the fields of agriculture using biotechnology principles. He has many scholarly publications in both international and local journals to his credits. 